УДК 631.559:[631.53.01:633.11"324"](477.7)

DOI https://doi.org/10.32848/agrar.innov.2021.10.10

\title{
ВЗАЄМОЗАЛЕЖНІСТЬ УРОЖАЙНОСТІ ЗЕРНА ПШЕНИЦІ ОЗИМОЇ 3 ВИСОТОЮ РОСЛИН В УМОВАХ ПІВДНЯ УКРАЇНИ
}

\author{
КОВАЛЕНКО О.А. - доктор сільськогосподарських наук \\ https://orcid.org/0000-0002-2724-3614 \\ Миколаївський національний аграрний університет \\ CMIPHOBA I.B. - кандидат сільськогосподарських наук \\ https://orcid.org/0000-0002-8976-3818 \\ Миколаївський національний аграрний університет
}

Постановка проблеми. В останні роки в Україні намітилася тенденція до зниження витрат на вирощування сільськогосподарських культур, у тому числі й зернових, а правильний підбір сорту та попередника під пшеницю озиму $є$ найдешевшим та ефективним засобом збільшення іїі врожайності [1].

Нині основним заходом припинення та запобігання розвитку негативних процесів і кризових явищ у землеробстві $€$ науково обґрунтована сівозміна, що відкриває додаткові можливості збільшення виробництва якісної сільськогосподарської продукції, зменшення витрат на її вирощування та позитивно впливає на стан довкілля [2].

3 усіх фракторів навколишнього середовища на формування рослинних організмів найбільше впливає режим живлення, який створюється обґрунтованим чергуванням культур у сівозміні та застосуванням оптимальної системи удобрення.

Аналіз останніх досліджень і публікацій. Для формування стабільних урожаїв та отримання повноцінного за якісним складом зерна пшениці озимої необхідно створювати оптимальне за макроелементами живлення рослин. Однією з важливих умов ефективного використання добрив $є$ визначення потреби рослин, враховуючи вміст їх рухомих сполук у ґрунті [3, 4].

Науково обґрунтована система живлення обов'язково включає позакореневе живлення макро- та мікроелементами, використання стимуляторів росту, що мають поліфункціональне призначення. Крім покращення живлення рослин, вони виступають як препарати-стресопротектори, виконуючи при цьому стимулюючу дію, захисні функції проти несприятливих умов довкілля, хвороб, поширення шкідників, і за чергування посушливих явищ та зволоження можуть забезпечити приріст врожаю до 5-15\% [5, 6, 7].

Правильним підбором попередника не лише створюють сприятливі умови на початку росту рослин пшениці, а й забезпечують формування кращого мікроклімату впродовж всього періоду вегетації. Встановлено, що за сівби пшениці озимої по кращих попередниках рослини більш раціонально використовують вологу впродовж всього періоду вегетації для фрормування врожайності з хорошими показниками якості, а також мають менше сумарне водоспоживання [8].

Раніше проведеними дослідженнями встановлено, що для пшениці озимої кращий попередник - чорний пар, після якого в ґрунті залишається більше азоту, ніж після непарових попередників [9].
Близькими за ефективністю до чистих парів $€$ зайняті та сидеральні пари та зернові бобові культури: горох, вика, кормові боби тощо. Вони поліпшують структуру ґрунту, не забирають із нього азот, зменшують забур'яненість. Горох є кращим непаровим попередником: він рано звільняє поля, залишаючи більше вологи в ґрунті порівняно з іншими непаровими попередниками [10, 11].

Матеріаліметодикадосліджень. Експериментальні дослідження проводили впродовж 2016-2019 рр. на дослідному полі Миколаївського НАУ. Об'єктом досліджень була пшениця озима. Технологія їх вирощування, за винятком досліджуваних факторів, була загальноприйнятою щодо існуючих зональних рекомендацій для південного Степу України.

Ґрунт дослідних ділянок представлений чорноземом південним, залишковослабкосолонцюватим важкосуглинковим на лесах. Реакція ґрунтового розчину нейтральна $(\mathrm{pH}-6,8-7,2)$. Вміст гумусу в шарі 0-30 см становить $3,3 \%$, рухомих форм елементів живлення в орному шарі ґрунту в середньому містилося: нітратів 18, рухомого фоссрору - 49, обмінного калію - 395 мг/кг ґрунту. Площа посівної ділянки - 50 м², облікової - 26 м², повторність 4-разова, розміщення ділянок послідовне.

Була передбачена така градація факторів та їх варіантів: попередники (A) - чорний пар, зернобобові (горох), хрестоцвіті (гірчиця яра); дози мінеральних добрив (В) - без основного внесення добрив, внесення $(\mathrm{NPK})_{32}$ кг.д.р./га, внесення (NPK) $)_{64}$ кг.д.р./га; бактеріальні препарати (C) - контроль, Біокомплекс-БТУ-р, Органік баланс.

Визначення динаміки висоти рослин проводили у трьох повтореннях за фразами розвитку рослин; збір урожаю проводили у фазу повної стиглості зерна способом прямого скошування комбайном Sampo-130. Урожайність зерна приводили до стандартної вологості [12]. Статистичний аналіз урожайних даних виконували за допомогою комп'ютерної програми Microsoft Exel, Agrostat методом дисперсійного і кореляційного аналізів [13].

Мета статі. Встановити залежність урожайності зерна пшениці озимої від висоти рослин за вирощування в умовах Півдня України.

Результати досліджень. Наші дослідження показали, що висота рослин пшениці озимої залежала від позакореневого підживлення бактеріальними препаратами, попередників та доз мінеральних добрив (табл. 1). 
Таблиця 1

Висота рослин пшениці озимої залежно від позакореневого підживлення бактеріальними препаратами, попередників та доз мінеральних добрив (середнє за 2016-2019рр.), см

\begin{tabular}{|c|c|c|c|c|c|}
\hline \multirow{2}{*}{$\begin{array}{c}\text { Обробка біопрепаратами } \\
\text { (фактор С) }\end{array}$} & \multicolumn{3}{|c|}{ Попередник (фактор А) } & \multicolumn{2}{|c|}{ 士 до контролю } \\
\hline & nap & ropox & гірчиця біла & CM & $\%$ \\
\hline \multicolumn{6}{|c|}{ Без застосування мінеральних добрив (фактор В) } \\
\hline Контроль & 79,1 & 77,2 & 75,6 & 77,3 & - \\
\hline Біокомплекс-БТУ-р & 80,7 & 79,0 & 77,5 & 79,1 & 1,8 \\
\hline Органік баланс & 81,3 & 79,6 & 78,0 & 79,6 & 2,3 \\
\hline Середнє по фактору А & 80,4 & 78,6 & 77,0 & 78,7 & 1,4 \\
\hline \multicolumn{6}{|c|}{ Мінеральне добриво (NPK) $)_{32}$ (фактор B) } \\
\hline Контроль & 82,0 & 80,6 & 79,1 & 80,6 & - \\
\hline Біокомплекс-БТУ-р & 83,2 & 82,2 & 80,6 & 82,0 & 1,4 \\
\hline Органік баланс & 83,5 & 82,7 & 81,2 & 82,4 & 1,8 \\
\hline Середнє по фактору А & 82,9 & 81,8 & 80,3 & 81,7 & 1,1 \\
\hline \multicolumn{6}{|c|}{ Мінеральне добриво (NPK) } \\
\hline Контроль & 83,8 & 82,8 & 81,5 & 82,7 & - \\
\hline Біокомплекс-БТУ-р & 84,8 & 84,1 & 82,6 & 83,8 & 1,1 \\
\hline Органік баланс & 85,1 & 84,7 & 83,5 & 84,4 & 1,7 \\
\hline Середнє по фактору А & 84,6 & 83,9 & 82,5 & 83,6 & 1,0 \\
\hline
\end{tabular}

У середньому за роки досліджень значно більшою висотою вирізнялися рослини пшениці озимої за вирощування їх на фоні внесення мінеральних добрив у дозі (NPK) $)_{64}$., висота коливалася в межах від 81,5 до 85,1 см залежно від попередника та позакореневого підживлення бактеріальними препаратами. За вирощування пшениці озимої після гірчиці білої рослини досягли висоти в межах 75,6-83,5 см, після гороху $77,2-84,7$ см, а після чорного пару цей показник збільшився і досяг 79,1-85,1 см.

Слід зазначити, що позакореневе підживлення суттєво впливало на висоту рослин пшениці озимої. Підживлення бактеріальним препаратом БіокомплексБТУ-р збільшувало висоту рослин у середньому по попередниках до 79,1 см без застосування мінеральних добрив. За внесення добрив у дозі (NPK) $)_{32}$ зазначений показник становив 82,0 cм, а за їі збільшення до $(\mathrm{NPK})_{64}-83,8 \mathrm{~cm}$.

Найбільшої висоти рослини пшениці озимої за вирощування по паровому попереднику досягли у варіанті 3 проведенням позакореневого підживлення бактеріальним препаратом Органік баланс по фону використання дози мінеральних добрив (NPK) 64 - 85,1 см.

Виходячи з вищевикладеного, ми вирішили визначити кореляційно-регресійні залежності між висотою рослин і врожайністю зерна пшениці озимої (рис. 1, 2, 3).

Як видно з даних, наведених на рис. 1, між висотою рослин та врожайністю зерна пшениці озимої існує дуже сильна кореляційно-регресійна залежність. Це підтверджує і ступінь статистичних зв'язків між досліджуваними показниками, яку характеризує коефіцієнт кореляції $\left(R^{2}\right)$.

Коефіцієнт кореляції, за нашими розрахунками, після попередника пар становить 0,964, горох - 0,946 та гірчиця біла - 0,990, тому ми можемо зробити висновок, у вищезазначених нами залежностях ступінь зв'язку за шкалою Чеддока є дуже сильним.
Розраховані нами поліноміальні кореляційно-регресійні залежності між висотою рослин та врожайністю зерна пшениці озимої свідчать, що за ії̈ вирощування обробкою біопрепаратами між зазначеними показниками існує дуже сильний зв'язок (рис. 2). Аналогічний результат отримали і за вирощування пшениці озимої без обробки біопрепаратами. Коефіцієнт детермінації $\left(R^{2}\right)$ становить 0,954-0,967.

Стосовно застосування мінеральних добрив під час вирощування пшениці озимої між вищезазначеними показниками існує дуже сильна залежність: при застосуванні варіанту без мінеральних добрив $\left(\mathrm{R}^{2}\right)$ становить 0,923, а мінерального добрива в дозі (NPK) $)_{32}$ $\left(R^{2}=0,912\right)$ (рис. 3). Але за подальшого збільшення дози мінерального добрива (NPK) 64 зв'язок між висотою рослин і врожайністю зерна пшениці озимої визначено сильним $\left(R^{2}=0,724\right)$, тому що коефіцієнт детермінації знаходиться в межах від 0,70 до 0,89, як у визначеній нами залежності, ступінь зв'язку за шкалою Чеддока вважається сильною.

Проведеними дослідженнями встановлено, що врожайність сортів пшениці озимої змінюється під впливом попередника, фону живлення, але значною мірою залежить від погодних умов року вирощування - перезимівлі та забезпеченості рослин упродовж вегетації вологою [14].

Нашими дослідженнями встановлено, що як в окремі роки вирощування, так і в середньому за роки досліджень урожайність зерна пшениці озимої вищою фрормувалася за розміщення по чорному пару (рис. 4).

Після гороху або гірчиці білої за вирощування без застосування мінеральних добрив, проте за обробки біопрепаратами вона у середньому була на 3,9-8,6\%, а з їх внесенням у дозі (NPK) $)_{64}$ - на 16,0-17,6\% нижчою відносно чорного пару (табл. 2).

У всі роки досліджень чітко простежується позитивна дія внесення мінеральних добрив. Більш істотні прирости врожаю зерна оптимізація живлення рослин 


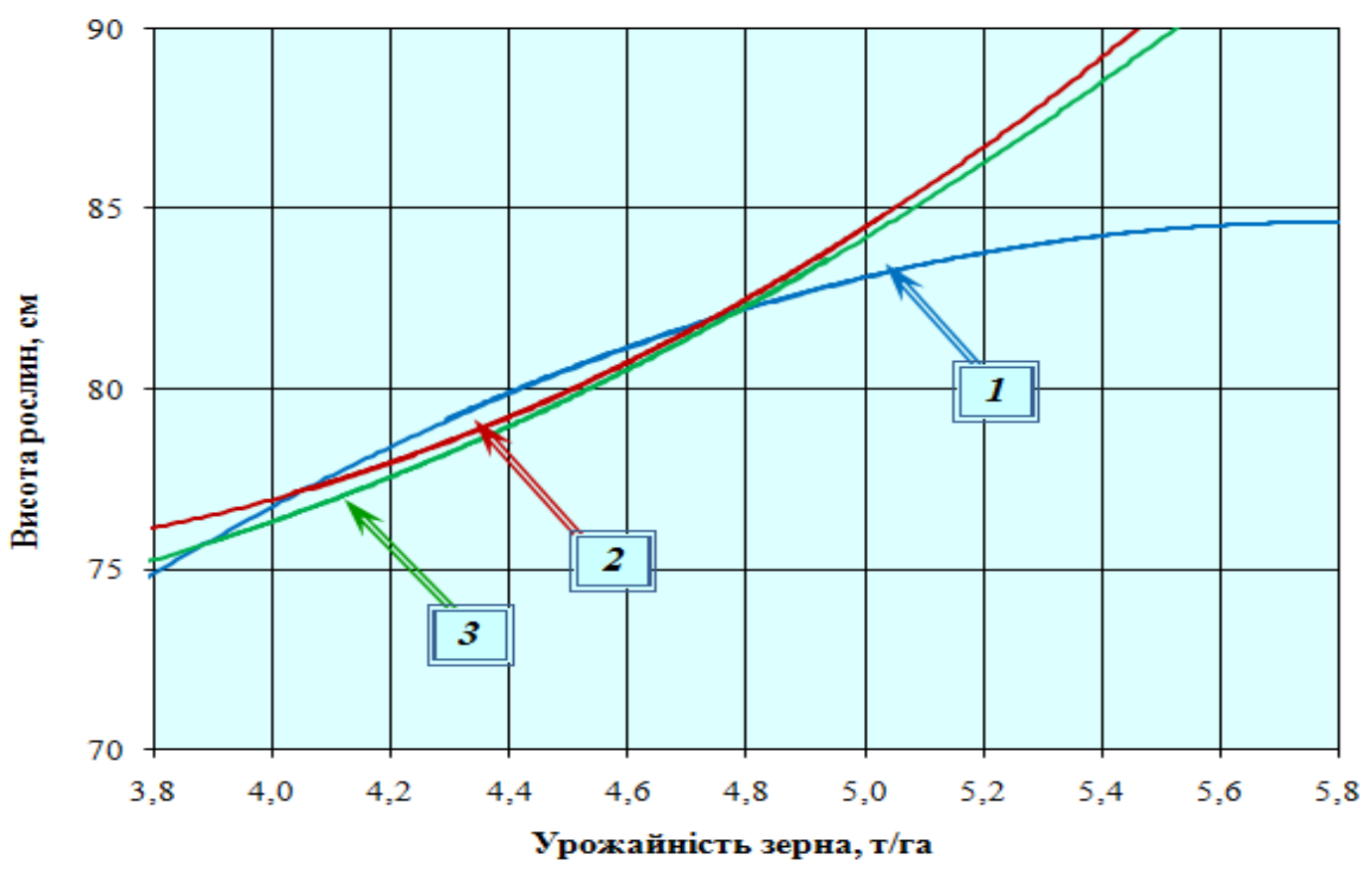

Puc. 1. Кореляційно-регресійна залежність урожайності зерна пшениці озимої від висоти рослин (середнє за 2016-2019 рр.)

Примітка: 1 - Пар: $\mathrm{y}=-2,540 \mathrm{x}^{2}+29,41 \mathrm{x}-0,347 ; \mathrm{R}^{2}=0,964$;

2 - Горох: $y=3,086 x^{2}-20,18 x+108,2 ; R^{2}=0,946$

3 - Гірчиця біла: $y=2,178 x^{2}-11,62 x+87,74 ; R^{2}=0,990$.

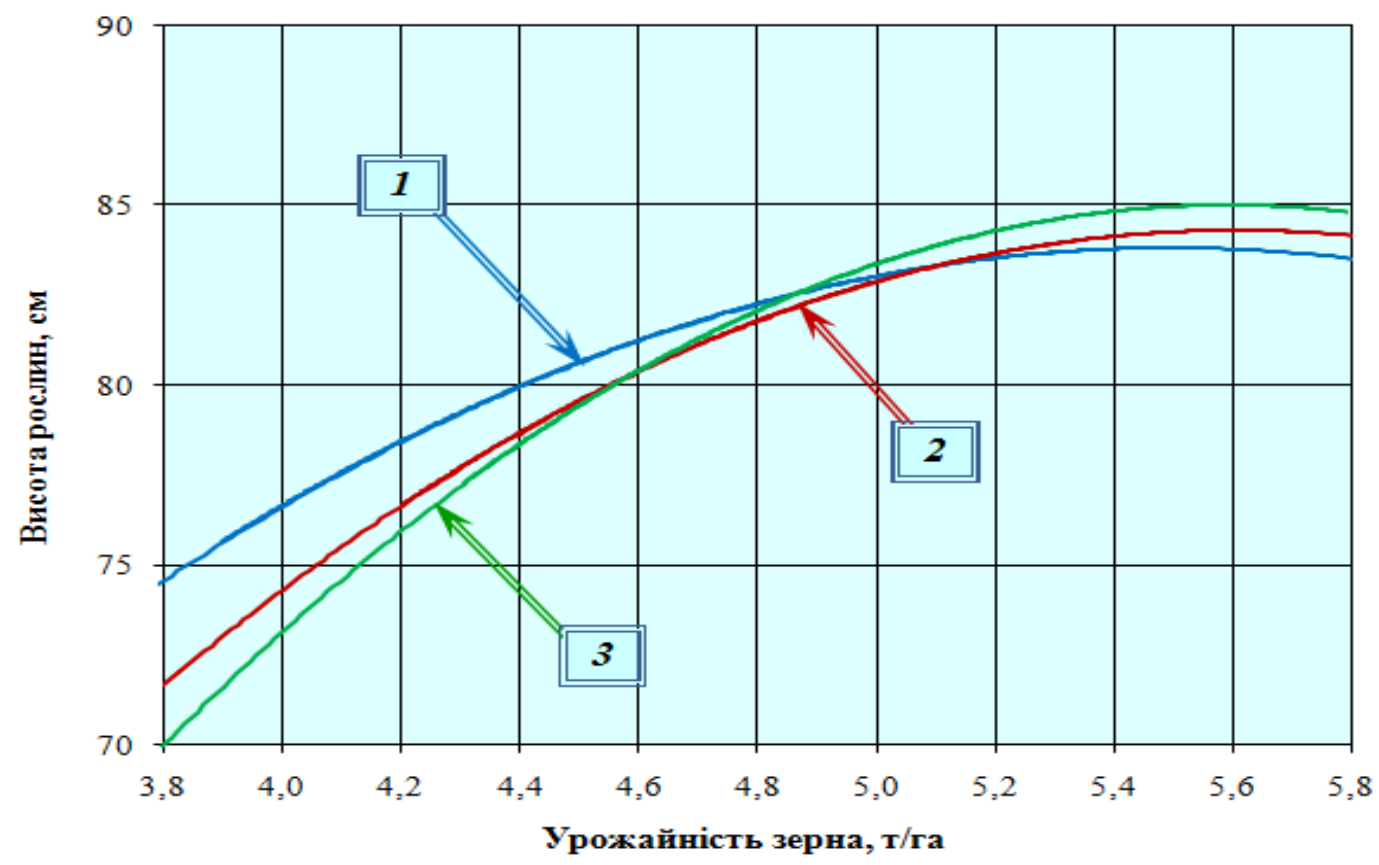

Puc. 2. Кореляційно-регресійна залежність урожайності зерна пшениці озимої від висоти рослин (середнє за 2016-2019 рр.)

Примітка: 1 - Контроль: $y=-3,327 x^{2}+36,57 x-16,58 ; R^{2}=0,954$;

2 - Біокомплекс-БТУ-р: $\mathrm{y}=-3,957 \mathrm{x}^{2}+44,35 \mathrm{x}-39,34 ; \mathrm{R}^{2}=0,967$;

3 - Органік баланс: $y=-4,836 x^{2}+54,15 x-66,19 ; R^{2}=0,955$. 


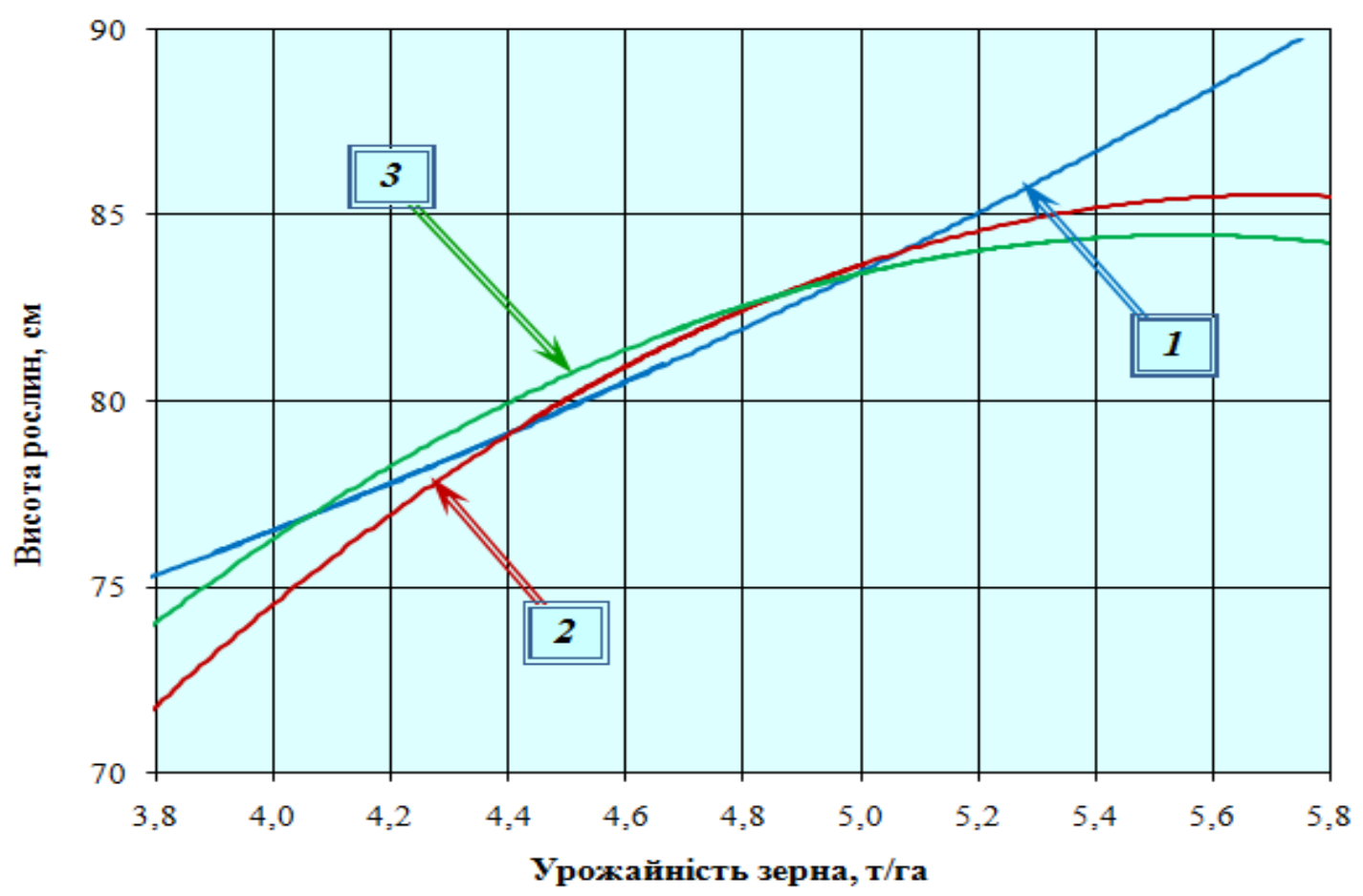

Puc. 3. Кореляційно-регресійна залежність урожайності зерна пшениці озимої від висоти рослин (середнє за 2016-2019 рр.)

Примітка: 1 - Без застосування мінеральних добрив: $y=0,839 x^{2}-0,406 x+64,62 ; R^{2}=0,923$;

2 - Мінеральне добриво (NPK) $)_{32}: \mathrm{y}=-3,760 \mathrm{x}^{2}+42,88 \mathrm{x}-36,95 ; \mathrm{R}^{2}=0,912$;

3 - Мінеральне добриво (NPK) $64: y=-3,476 x^{2}+38,62 x-22,40 ; R^{2}=0,724$.

Урожайність, т/га

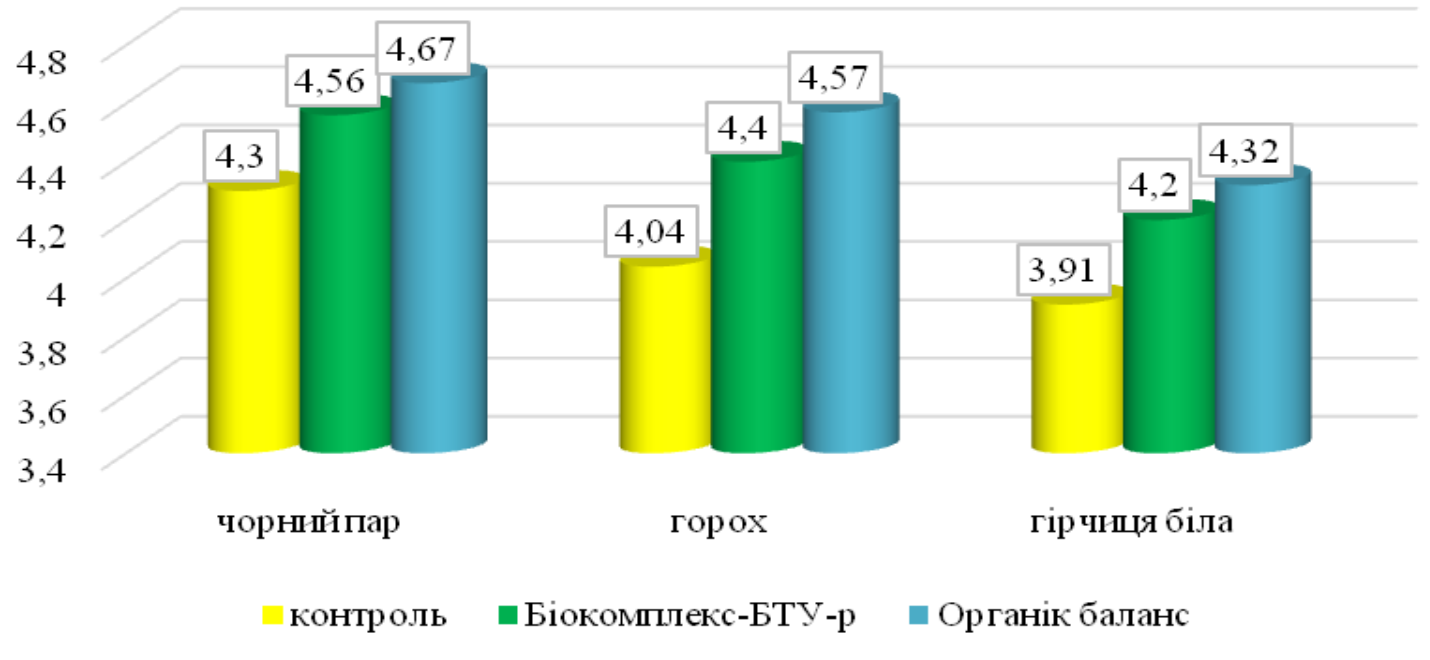

Рис. 4. Урожайність зерна пшениці озимої залежно від попередника та впливу обробки бактеріальними препаратами без застосування мінеральних добрив (середнє за 2016-2019 pp.), m/гa 
Таблиця 2

Урожайність пшениці озимої залежно від позакореневого підживлення бактеріальними препаратами, попередників та доз мінеральних добрив (середнє за 2016-2019 рр.), т/га

\begin{tabular}{|c|c|c|c|c|c|c|}
\hline \multirow{2}{*}{$\begin{array}{l}\text { Обробка біопрепаратами } \\
\text { (фактор С) }\end{array}$} & \multicolumn{3}{|c|}{ Попередник (фактор А) } & \multirow{2}{*}{ Середнє } & \multicolumn{2}{|c|}{ 士 до контролю } \\
\hline & nap & ropox & гірчиця біла & & $\mathbf{C M}$ & $\%$ \\
\hline \multicolumn{7}{|c|}{ Без застосування мінеральних добрив (фактор В) } \\
\hline Контроль & 4,30 & 4,04 & 3,91 & 4,08 & - & - \\
\hline Біокомплекс-БТУ-р & 4,56 & 4,40 & 4,20 & 4,39 & 0,30 & 7,43 \\
\hline Органік баланс & 4,67 & 4,57 & 4,32 & 4,52 & 0,44 & 10,69 \\
\hline Середнє по фактору А & 4,51 & 4,34 & 4,14 & 4,33 & 0,25 & 6,04 \\
\hline \multicolumn{7}{|c|}{ Мінеральне добриво (NPK) $)_{32}$ (фактор B) } \\
\hline Контроль & 4,66 & 4,54 & 4,44 & 4,55 & - & - \\
\hline Біокомплекс-БТУ-р & 4,94 & 4,80 & 4,64 & 4,79 & 0,25 & 5,43 \\
\hline Органік баланс & 5,01 & 4,85 & 4,74 & 4,87 & 0,32 & 7,04 \\
\hline Середнє по фактору А & 4,87 & 4,73 & 4,61 & 4,74 & 0,19 & 4,15 \\
\hline \multicolumn{7}{|c|}{ Мінеральне добриво (NPK) $)_{64}$ (фактор B) } \\
\hline Контроль & 5,48 & 4,7 & 4,67 & 4,95 & - & - \\
\hline Біокомплекс-БТУ-р & 5,73 & 4,94 & 4,84 & 5,17 & 0,22 & 4,44 \\
\hline Органік баланс & 5,79 & 5,03 & 4,94 & 5,25 & 0,30 & 6,13 \\
\hline Середнє по фактору А & 5,67 & 4,89 & 4,82 & 5,12 & 0,17 & 3,52 \\
\hline HIP $_{05 \text { по фактору A }}$ & 0,17 & 0,11 & 0,10 & & & \\
\hline HIP $_{05 \text { по фактору }}$ & 0,22 & 0,14 & 0,11 & & & \\
\hline HIP $_{05 \text { по фактору C }}$ & 0,23 & 0,15 & 0,13 & & & \\
\hline
\end{tabular}

пшениці озимої забезпечує за вирощування культури по непарових (більш збіднених на елементи живлення) попередниках. Важливо при цьому звернути увагу, що з покращенням поживного режиму рослини пшениці озимої навіть у несприятливому 2017 році не так істотно знизили врожайність за вирощування після гороху та гірчиці білої порівняно з чорним паром. Можна зазначити, що за оптимізації живлення рослин значення попередника дещо нівелюється, а віддача від внесених мінеральних добрив зростає на більш збіднених на елементи живлення ґрунтах.

Висновки. Урожайність зерна пшениці озимої значною мірою залежить і змінюється під впливом погодних умов вегетаційного періоду, забезпеченості рослин елементами живлення та позакореневого підживлення бактеріальними препаратами. Із досліджуваних нами бактеріальних препаратів найбільший приріст урожаю забезпечує підживлення бактеріальним препаратом Органік баланс, а найнижчий - Біокомплекс-БТУ-р. Незалежно від погодних умов року вирощування значно вищою врожайність зерна пшениці озимої формується по чорному пару. Рівень урожаю зерна істотно зростає за внесення під культуру мінеральних добрив, причому більшою мірою по збіднених попередниках - гороху та гірчиці білій.

\section{СПИСОК ВИКОРИСТАНОÏ ЛІТЕРАТУРИ}

1. Гудзь В.П. Пути повышения продуктивности интенсивных сортов озимой пшеницы. Киев: Урожай, 1989. $132 \mathrm{c}$.

2. Патік С. Короткоротаційні сівозміни в умовах Степу України. Пропозиція. 2010. № 2. С. 47-51.

3. Розпутній М.В. Вирощування високоякісного зерна озимої пшениці та аспекти раннього прогнозування білковості. Науковий вісник НАУ, 1998. № 5. С. 265-268.
4. Агротехнологічні вимоги до сівби озимих культур під урожай 2019 року у Південному Степу України : науково-практичні рекомендації / уклад. : Р.А. Вожегова, С.О. Заєць, А. М. Коваленко [та ін.]. Миколаїв, 2018. 44 с.

5. Шевчук О.А., Кришталь О.О., Шевчук В.В. Екологічна безпека та перспектива застосування синтетичних регуляторів росту рослин. Вісник Вінницького політехнічного інституту. 2014. № 1(112). С. 34-39.

6. Григоришин В.В. та ін. Екологічна безпека застосування інгібіторів росту рослин. Matezialy XII Miedzynazodowej monkowi-pzactyaznej Konferenej «Naukowa myse informecyjne pomieki, 2016». Vol. 11. Przemyse i Nauke i studia, 2016. S. 30-31.

7. Гамаюнова В.В. та ін. Сучасні підходи до застосування мінеральних добрив за збереження грунтової родючості в умовах зміни клімату. Наукові горизонти, Scientific horizons. 2020. № 2 (87). С. 89-101.

8. Кудря С.И., Клочко Н.А., Кудря Н. А. Влагообеспеченность и урожайность пшеницы озимой в зависимости от предшественника. Вісник аграрної науки. Київ, 2007. № 7. С. 23-26.

9. Карпова А.В. Влияние предшественников на урожай семян пшеницы. Земледелие. 2002. № 2. С. 25-26.

10. Кимак Я.В. Економічна та енергетична ефективність, технології вирощування пшениці озимої в умовах північного Лісостепу. Науковий вісник Національного університету біоресурсів і природокористування. Київ. 2010. Вип. 145. С. 150-156.

11. Ярчук І.І., Сахаров В.Д. Вплив строків сівби, попередників і режимів живлення на якість зерна озимої пшениці. Асрохімія $i$ грунтознавство. Міжвідомчий тематичний науковий збірник. Харків, 2002. Вип. 63. С. 75-77.

12. Рожков А.О., Пузік В.К., Каленська С.М. та ін. Дослідна справа в агрономії : навч. посібник : Статистична 
обробка результатів агрономічних досліджень / за ред. А. О. Рожкова. Харків : Майдан, 2016. 342 с.

13. Ушкаренко В.О., Нікішенко В.Л., Голобородько С.П., Коковіхін С.В. Дисперсійний і кореляційний аналіз у землеробстві та рослинництві : навч. посіб. Херсон : Айлант 2008. 272 с

14. Гамаюнова В.В., Литовченко А.О., Музика Н.М. Значення попередника у формуванні зернової продуктивності озимих культур в умовах Степу України. Вісник ЖНЕАУ. №1(53). 2016. С. 80-87.

\section{REFERENCES:}

1. Gudz, V.P. (1989). Puti povyshenija produktivnosti intensivnyh sortov ozimoj pshenicy. [Ways to increase the productivity of intensive winter wheat varieties]. Kiev: Urozhaj [in Russian].

2. Patik, S. (2010). Korotkorotacijni sivozminy v umovakh Stepu Ukrajiny [Short-cut performances in the minds of Stepu Ukraine]. Propozycija - Proposition, 2, 47-51 [in Ukrainian].

3. Rozputnij, M.V. (1998). Vyroshhuvannja vysokojakisnogho zerna ozymoji pshenyci ta aspekty rannjogho proghnozuvannja bilkovosti [Growth of high-yield grain of winter wheat and aspects of early prognosis of bleakness]. Naukovyj visnyk NAU - Scientific bulletin of $N A U, 5,265-268$ [in Ukrainian].

4. Vozheghova, R.A. et al. (2018). Aghrotekhnologhichni vymoghy do sivby ozymykh kuljtur pid urozhaj 2019 roku u Pivdennomu Stepu Ukrajiny [Agrotechnological vimogi to sivbi winter crops for the harvest of 2019 at the Pivdenny Stepu of Ukraine]. Mykolajiv [in Ukrainian].

5. Shevchuk, O.A., Kryshtalj, O.O., \& Shevchuk, V.V. (2014). Ekologhichna bezpeka ta perspektyva zastosuvannja syntetychnykh reghuljatoriv rostu Roslyn [Ecological safety and the prospect of storing synthetic regulators in the growth of roslin]. Visnyk Vinnycjkogho politekhnichnogho instytutu - Visnik of the Vinnytsia Polytechnic Institute, 1(112), 34-39 [in Ukrainian].

6. Ghryghoryshyn, V.V. etal. (2016). Ekologhichna bezpeka zastosuvannja inghibitoriv rostu roslyn [Ecological safety for the growth of roslin]. Naukowa myse informecyjne pomieki: matezialy XII Miedzynazodowej monkowi-pzactyaznej Konferenej. Przemyse i Nauke $i$ studia (pp. 30-31) [in Ukrainian].

7. Ghamajunova, V.V. et al. (2020). Suchasni pidkhody do zastosuvannja mineraljnykh dobryv za zberezhennja ghruntovoji rodjuchosti $v$ umovakh zminy klimatu [Modern approaches to the use of mineral fertilizers while maintaining soil fertility in climate change]. Naukovi ghoryzonty - Scientific horizons, 2 (87), 89-101 [in Ukrainian].

8. Kudrja, S.I., Klochko, N.A., \& Kudrja, N.A. (2007). Vlagoobespechennost' i urozhajnost' pshenicy ozimoj v zavisimosti ot predshestvennika [Moisture provision and yield of winter wheat depending on the predecessor]. Visnik agrarnoï nauki - Bulletin of Agricultural Science, 7, 23-26 [in Russian].

9. Karpova, A.V. (2002). Vlijanie predshestvennikov na urozhaj semjan pshenicy [The influence of predecessors on the yield of wheat seeds]. Zemledelie - Agriculture, 2, 25-26 [in Russian].

10. Kymak, J.V. (2010). Ekonomichna ta energhetychna efektyvnistj, tekhnologhiji vyroshhuvannja pshenyci ozymoji v umovakh pivnichnogho Lisostepu [Economic and energy efficiency, technologies growing winter wheat in the northern forest-steppe]. Naukovyj visnyk Nacionaljnogho universytetu bioresursiv i pryrodokorystuvannja - Scientific Bulletin of the National University of Life and Environmental Sciences, 145, 150-156 [in Ukrainian].

11. Jarchuk, I.I., \& Sakharov, V.D. (2002). Vplyv strokiv sivby, poperednykiv i rezhymiv zhyvlennja na jakistj zerna ozymoji pshenyci [Influence of sowing dates, precursors and feeding regimes on winter wheat grain quality]. Aghrokhimija i gruntoznavstvo. Mizhvidomchyj tematychnyj naukovyj zbirnyk - Agrochemistry and soil science. Interdepartmental thematic scientific collection, 63, 75-77 [in Ukrainian].

12. Rozhkov, A.O. et al. (2016). Doslidna sprava $v$ aghronomiji: navch. posibnyk: Statystychna obrobka rezuljtativ aghronomichnykh doslidzhenj [Research in agronomy: textbook. manual: Statistical processing of agronomic research results]. Kharkiv: Majdan [in Ukrainian].

13. Ushkarenko, V.O., Nikishenko, V.L., Gholoborodjko, S.P., \& Kokovikhin, S.V. (2008). Dysersijnyj i koreljacijnyjp analiz $u$ zemlerobstvi ta roslynnyctvi [Analysis of variance and correlation in agriculture and crop production]. Kherson: Ajlant [in Ukrainian].

14. Ghamajunova, V.V., Lytovchenko, A.O., \& Muzyka, N.M. (2016). Znachennja poperednyka u formuvanni zernovoji produktyvnosti ozymykh kuljtur $v$ umovakh Stepu Ukrajiny [The importance of the predecessor in the formation of grain productivity of winter crops in the steppe of Ukraine]. Visnyk ZhNEAU - Bulletin of ZHNEAU, 1 (53) 80-87 [in Ukrainian].

Коваленко О.А., Смірнова І.В. Взаємозалежність урожайності зерна пшениці озимої з висотою рослин в умовах Півдня України

Мета - встановити залежність між урожайністю зерна пшениці озимої та висотою рослин при вирощуванні в умовах Півдня України. Методи. Експериментальні дослідження проводили впродовж 2016-2019 рр. на дослідному полі Миколаївського НАУ. Об'єктом досліджень була пшениця озима. Технологія їх вирощування, за винятком досліджуваних факторів, була загальноприйнятою щодо існуючих зональних рекомендацій для південного Степу України. Площа посівної

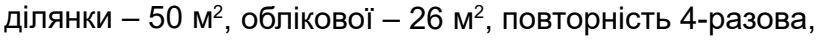
розміщення ділянок послідовне. Була передбачена така градація фракторів та їх варіантів: попередники (A) - чорний пар, зернобобові (горох), хрестоцвіті (гірчиця яра); дози мінеральних добрив (B) - без основного внесення добрив, внесення (NPK) ${ }_{32}$ кг.д.р./га, внесення $(\mathrm{NPK})_{64}$ кг.д.р./га; бактеріальні препарати (C) - контроль, Біокомплекс-БТУ-р, Органік баланс. Результати. Нашими дослідженнями встановлено, що як в окремі роки вирощування, так і в середньому за роки досліджень урожайність зерна пшениці озимої вищою формувалася за розміщення по чорному пару. Після гороху або гірчиці білої за вирощування без застосування мінеральних добрив проте за обробки біопрепаратами вона у середньому була на 3,9-8,6\%, а з їх внесенням у дозі (NPK) 64 - на 16,0-17,6\% нижчою відносно чорного пару. Розраховані нами поліноміальні кореляційно-регресійні залежності між висотою рослин та врожайністю зерна пшениці озимої, свідчать, що за її вирощування оброб- 
кою біопрепаратами між зазначеними показниками існує дуже сильний зв'язок. Висновки. Дослідженнями встановлено, що між висотою рослин та врожайністю зерна пшениці озимої існує дуже сильна кореляційно-регресійна залежність. Урожайність зерна пшениці озимої значною мірою залежить і змінюється під впливом погодних умов вегетаційного періоду, забезпеченості рослин елементами живлення та позакореневого підживлення бактеріальними препаратами. Із досліджуваних нами бактеріальних препаратів найбільший приріст урожаю забезпечує підживлення бактеріальним препаратом Органік баланс, а найнижчий - Біокомплекс-БТУ-р.

Ключові слова: обробка бактеріальними препаратами, попередник, дози мінеральних добрив, кореляційно-регресійна залежність, позакореневого підживлення.

Kovalenko O.A., Smirnova I.V. Interdependence of Winter Wheat Grain Yield with Plant Height in the Conditions of Southern Ukraine

The goal was to establish the relationship between the yield of winter wheat grain and the height of plants when grown in the south of Ukraine. Methods. Experimental studies were conducted during 2016-2019 yrs in the experimental field of the Mykolaiv NAU. The object of research was winter wheat. The technology of their cultivation, with the exception of the studied factors, was generally accepted to the existing zonal recommendations for the Southern Steppe of Ukraine. The area of the sown area was $50 \mathrm{~m}^{2}$, the accounting area was $26 \mathrm{~m}^{2}$, the repetition was 4-time, the placement of plots was consistent. It was predicted the following gradation of factors and their variants, such as predecessors (A) - black fallow, legumes (peas), cruciferous (spring mustard); doses of mineral fertilizers (B) - without basic fertilizer application, application of (NPK) $32 \mathrm{~kg} . D$. R. / ha, application of (NPK) $64 \mathrm{~kg}$.D. R./ha; bacterial preparations (C) - control, Biocomplex-BTU-R, Organic Balance. Results. Our research established that both in some years of cultivation and on average over the years of research, the yield of winter wheat grain was higher when placed on Black fallow. After peas or white mustard, when it was grown without the use of mineral fertilizers, but when treated with biologics, the yield was on average by $3.9-8.6 \%$, and with their application at a dose of (NPK) 64 it was lower by $16.0-17.6 \%$ relative to black fallow. The polynomial correlation and regression relationships were calculated between plant height and winter wheat grain yield as they indicated that there was a very strong relationship between these indicators when the winter wheat was grown and treated with biologics. Conclusions. Studies established that there was a very strong correlation and regression relationship between plant height and winter wheat grain yield. The yield of winter wheat grain largely depended and changed under the influence of weather conditions of the growing season, the supply of plants with nutrients and foliar top dressing with bacterial preparations. As for studied the bacterial preparations the largest increase in yield was provided by top dressing with the bacterial preparation Organic Balance, and the lowest increase was provided by Biocomplex-BTU-R.

Key words: treatment with bacterial preparations, precursor, mineral fertilizer doses, correlation and regression dependence, foliar top dressing. 